\title{
Translation Encounters and the Histories of Globalization
}

\author{
Inglis, David
}

Routledge

2020-12-31

Inglis , D \& THorpe , C 2020 , Translation Encounters and the Histories of Globalization . in

E Bielsa \& D Kapsaskis (eds), The Routledge Handbook of Translation and Globalization ., 1 , Routledge Handbooks in Translation and Interpreting Studies, Routledge, London .

http://hdl.handle.net/10138/338912

cc_by_nd

acceptedVersion

Downloaded from Helda, University of Helsinki institutional repository.

This is an electronic reprint of the original article.

This reprint may differ from the original in pagination and typographic detail.

Please cite the original version. 


\title{
Translation Encounters and the Histories of Globalization
}

\author{
David Inglis, University of Helsinki
}

Christopher Thorpe, University of Exeter

\section{Introduction}

Understanding the nature of translation practices in relation to globalization processes necessarily involves careful historical consideration of both. This is a challenging endeavour, because there is no generally shared understanding either of what 'globalization' entails, or of its history. But no matter how one defines globalization, with however many phenomena and whatever types of processes it is assumed to involve, and however long one thinks its history is, it is certainly the case that translation must be regarded as central to globalization dynamics (Cronin, 2003, Bielsa, 2014, 2016).

The term 'globalization' in one way or another refers to processes of connectivity, whereby some people in some places are brought into new forms of connection with other people in other places. In any specific case, there is a good chance that each group will not speak or read the same language as the other. Hence processes of translation are crucial for globalization, because they allow connections to happen in the first place, and then can profoundly shape how those connections develop over time (Chanda, 2007).

In this chapter we will not adopt any one viewpoint on what globalization is or when it began, but we will instead keep an open mind about such matters. This is so that the broadest possible analysis can be offered of globalization/translation interfaces, as these have occurred over the centuries in different places, and in so doing have brought different places and people into new forms of connectivity and interaction.

We will first set out the various possible answers to the interconnected questions what is globalization and when did it begin? Then we will consider how translation activities are bound up with globalization processes, first in terms of the actions of the human actors who do the translations, and then the locations where translations are carried out. Finally, we will illustrate the general points raised in these earlier sections with some illustrative examples drawn from Eurasia from ancient times until the start of the modern era. In this way we will attempt to map out the connections between historical modes of globalization and forms of translation practices, in ways that to our knowledge no-one has yet attempted.

\section{Defining Globalization and Its History}

Among scholars today, there is no consensus as to what 'globalization' entails, or what its history involves. The definitional and historiographical aspects are deeply intertwined: how one defines globalization entails specific understandings of its history, and vice versa. Narrating the history of 'globalization' involves making a series of assumptions - about what the term refers to, which processes it encompasses (and which it does not), how the various processes can be understood to connect with each other, and, crucially, when globalization is meant to have 'begun'. Opinions on the latter issue vary greatly, from positions which see globalization as a very recent set of phenomena - perhaps dating from about the time of the fall of the Berlin Wall - to viewpoints which regard globalization as involving very long-term processes that have operated over thousands of years (Inglis, 2005). 
There is a large and complex literature in which various specialists - such as historians, and historically-oriented economists, sociologists, anthropologists, and others - debate the vexed issue of when globalization 'began'. There are various possible responses, varying in chronological extent. First, globalization is at least several thousand years old, perhaps stretching back as much as 5000 years. Second, globalization can be found in the ancient world, in the two millennia before and after the time of Christ. Third, globalization could have started in the period after the fall of the Roman empire, or in the early medieval world. Fourth, globalization begins around about 1500CE, around the time of the European conquest of the Americas, and the start of modern capitalism in Europe. Fifth, globalization starts in either the $18^{\text {th }}$ or $19^{\text {th }}$ centuries CE, with the coming to dominance of the European empires across the planet, and then the industrial revolution in Europe. Sixth, some scholars assert that globalization only really takes off in the $20^{\text {th }}$ century, either in the aftermath or WWII, or with the development of new features of the capitalist economy in the 1970s, or with the end of Soviet Communism in the late 1980s. or with the rise of internet and related communications technologies in the 1990s (for overviews, see Bentley, 1999, 2006, Hopkins, 2002, McKeon, 2007, Pieterse, 2012).

As can be seen from this list, practically any period of human history can be chosen as the starting point of globalization. The choice is wholly dependent on how any given analyst defines globalization, and which phenomena they choose to focus on as evidence of globalization's apparent beginnings. Once a starting point has been chosen, a model can be created of what that analyst believes were the periods that variously a) were wholly "before" globalization; b) created the conditions for, and acted as the run-up to, globalization (such periods are often referred to as those of "proto-globalization"); c) involved the beginning of "globalization" per se; d) constitute the subsequent phases of globalization, from the beginning period up until our own time (Bayly, 2002). Howsoever more "modern" phases of globalization may be conceived, it is important not to assume that these are either completely different from pre-modern variants, or, conversely, are just bigger and more expansive versions of previous phases. Each phase may build on previous ones, or involve ruptures with them (Bentley, 1999).

The scope for dispute and confusion in labelling the different alleged periods of globalization is potentially endless. Periods that some scholars refer to as "archaic" globalization (Bayly, 2002), others refer to as not involving globalization at all, or conversely as "protoglobalization". There is some consensus among scholars that the period around $1500 \mathrm{CE}$ is somehow special. This partly reflects an apparently commonsensical assumption: surely globalization only really begins when most of the planet is involved in its processes? If so, then given that the Americas were only pulled into systematic connection with Eurasia and Africa after that point, with Australasia following a little later, it must be the case that globalization 'proper' only really begins at the turn of the $16^{\text {th }}$ century CE. The European conquest of the Americas must therefore be understood as the great turning-point in the emergence of planetwide connectivity.

This idea sounds plausible on the surface. But if there is anything that the debate about the beginnings of globalization can teach us is that common-sense assumptions do not pass muster when put under historical scrutiny. Focusing on the period about $1500 \mathrm{CE}$ is deeply Eurocentric. It assumes that globalization, and more broadly world history, pivot on relatively recent European interventions. It also assumes a diffusionist model, where action emanates from a Western centre, spreading outwards to non-Western peripheries, instead of recognising that the circulation of people, ideas, languages and objects over time has been much more complex and multicentric than that (Olohan, 2014). 
Such a chauvinist and parochial viewpoint omits many other things too: that much of the forms of human connectivity throughout planetary history were created in other parts of the globe beyond Europe; that the Europeans were late starters in this regard; that much of Europe's alleged distinctiveness and innovative nature was borrowed, usually in unacknowledged ways, from other civilizations, notably China; and that over-emphasis on the role of the so-called 'West' goes together with the equally untenable assumption that globalization must be wholly 'modern' in nature. Given that there were extensive trade networks across Eurasia and subSaharan Africa many centuries before $1500 \mathrm{CE}$, one could argue that globalization was well in place before then (Frank and Gills, 1993). So, what if globalization is as much to be found in, say, $13^{\text {th }}$ century CE Mongolia as it is in $19^{\text {th }}$ century CE London? What if evidence points us towards finding the presence of globalization at times, and in places, including "pre-modern" ones, that Eurocentric and modernist thinking has trained us not to look at?

Both contemporary globalization studies and translation history have become over the last 20 years more attuned to understanding history in non-Eurocentric ways, which emphasize instead trans-regional flows and circulations, and polycentric complexity (Bandia, 2006). Such a shift in emphasis has great implications for how translation in history is understood and studied. Up until quite recently, translation studies and translation history could be accused of deep Eurocentrism. This took various forms. One was uncritically using Judeo-Christian timeframes (ancient, medieval, modern, etc.) as if these were somehow natural and applicable the world over. Another was assuming that the civilizations like ancient Judea, Greece, and Rome, from which came the great, canonised texts like the Bible - which scholars primarily focused on, while ignoring more mundane writings - were simply coherent and self-contained cultural totalities (Bandia, 2006).

But once one looks at the world through the lens of globalization theory, which itself has been sensitized by post-colonial thinking to recognize historical complexity and difference, things look very different. As Appiah (1995: 55) writes:

The Greece to which the West looks back was at the crossroads of cultures of North Africa and the Near East; the Spain that began the conquest of the New World had been deeply shaped by Islam; the Renaissance rediscovery of ancient learning owed a great deal to the Arabs who had preserved that tradition through the European Dark Ages; and the economic basis of modern capitalism depended on the labour of Africans, the gold and silver of the New World Indians, and the markets of Asia ... The West acquired gunpowder - at the military heart of the modern European state - from China and the astronomical data on which was based the beginnings of the Scientific Revolution from the ancient Near East.

So what may seem like self-enclosed cultural and civilizational entities are in fact hybrids, and indeed one way to describe the history of globalization is to say that it is the history of different socio-cultural entities coming into contact, and new entities being created in the process. Such hybridization is made possible in and through translation practices, both those that are more explicit and, perhaps more often, hidden and subterranean.

'Translation' here means two things: first, something more general - ideas and cultural influences from some groups are adopted, adapted and transformed by others; and second, something more precise - the adoption, adaptation and transformation had to operate somehow through linguistic means. Translation practices have been the means through which different groups, cultures and civilizations have influenced each other, and have thereby created new, hybrid entities, the mixed nature of which has often been subsequently denied. But the complex mixing that has happened becomes apparent again when we look at such matters in light of globalization processes, and this becomes even more clear when we understand these globalization processes as themselves involving complicated practices of translation. 


\section{Connections and Actors}

The connections involved in, and made through, globalization processes can be of a potentially infinite variety. But certain types have reoccurred again and again over time across the world. They include forms of peaceful and constructive interchange, as well as violent forms of control and domination. They can involve face-to-face contacts between specific persons, or more indirect, impersonal and mediated connections. They can be of a more economic nature (e.g. trading connections), or of a more political type (e.g. imperial conquests, and resistance to those by the colonised), or of a more cultural sort (e.g. religious conversions). It is likely that some or all of these types will be intermingled in any given real-world case (Holton, 2005).

Each type of connection, and how they may mix with each other, is made possible by, and depends on, associated translation processes. For example, different groups can only keep trading with each other, and so bring their parts of the world into economic connection, if they work out some sort of way of communicating, involving translating between two or more languages. The history of economic globalization (or as some scholars would prefer to say, the economic facets of globalization) is full of instances of 'pidgin' languages being created to allow trading relations to operate. Likewise, what we can call political globalization (how different political units, such as nation-states or empires, relate to each other) is dependent on translation practices. An invading army needs interpreters to speak with the local population, to gain crucial information and co-opt local knowledges. A conquering power will need to find ways to communicate with the conquered, and to impose its own language upon them in some ways, such as by demanding that official business be conducted only in the conquerors' language, and by rendering place and street names into the dominant language. Yet conquerors may also live in fear of the potential duplicity of native translators, who might feed the masters faulty information (Cronin, 2000).

Religious globalization (which primarily involves the spread of belief systems across territories) partly relies on missionaries being able to talk with potential converts in ways that the latter understand (Chanda, 2007). Conversion often means the converted adopting the language of the missionaries and therefore of the holy texts that they venerate. The same sort of point applies to other types or facets of globalization. Cultural globalization (the spread of ideas and imageries across space) and social globalization (the creation of new sorts of social relationships across distances, including between people who were previously disconnected, in whole or in part) also rely on translation practices (Inglis with Thorpe, 2019).

Focusing on translating and interpreting encounters allows us to see some of the very concrete practices that make up the micro-level aspects of wider and bigger globalization processes. A good way to understand how translation practices and globalization processes have intersected and made each other possible at different times and places involves focusing on the people who did the actual translation and interpreting work, in so doing operating as brokers between one group and another. This focus chimes with contemporary approaches in translation history, which are less interested in translated texts taken in isolation, and more interested in how everyday translation work was done, by whom, and with which tools (Cronin, 2003). Sometimes those doing translation have been individuals or groups who have explicitly been understood by their contemporaries as professional 'translators'. There have also been those who were not recognised as professionals, but who nonetheless undertook translation activity on an everyday basis, such as merchants who dealt with people from different language groups as part of their day-to-day transactions (Holton, 2005). 
There have also been people who were defined by those around them as 'interpreters', who are a much less studied group than translators. This is partly because, often working in spoken rather than written language, and for everyday pragmatic reasons rather than for scholarly purposes, they have left behind far fewer visible traces than have the translators (Santoyo, 2006). But despite their relative invisibility to us (Venuti, 1995), interpreters are some of the most important, if unsung, makers of globalization processes. In addition to doing on-the-spot oral translations, they also produced 'texts, most of them, of a pragmatic, matter-of-fact condition, which ... [for a very long] time have been present almost daily at school, at court, at church, in monasteries and chanceries, on routes of pilgrimage, at ports, harbours, and interstate frontiers' (Santoyo, 2006: 16). In so doing, interpreters have significantly created the everyday fabric of globalization across the centuries, helping to forge day in and day out the sorts of linkages and connections that the umbrella term 'globalization' refers to.

Translators of various sorts, as well as interpreters, have often been migrants, sometimes possessed of multiple and/or hybrid identities (Cronin and Simon, 2014). Sometimes they have taken on more passive or more active roles in inter-language brokerage (Demirkol-Erturk and Paker, 2014). Some have been in a position not only to traverse, but also to transgress, linguistic and cultural boundaries (Meylaerts and Gonne, 2014). They have come from, and occupied, both higher and lower social positions, ranging from the honoured translator of sacred texts through to the humble servant or slave who interprets for their master (Koskinen, 2014). Translators and interpreters have often come from outsider or nomadic groups, such as the Jews (Steiner, 1996), or those who have been displaced by political and economic circumstances, such as the Huguenots and Irish Catholics (Cronin, 2000).

Historians of translation practices know that translation has occurred in relation to, and as part of, many other sorts of transfers and exchanges (D'hulst, 2012). Much translation and interpreting work throughout history - and therefore throughout the history of globalization was done not by professionals, but instead improvised by those engaged primarily in other occupations which required linguistic interchange. The list here would include people like traders, business people, financiers, soldiers, sailors, political administrators, diplomats, spies, priests, missionaries, and other types of person (Chanda, 2007, Santoyo, 2006, Cronin, 2000, Roland and Delisle, 1999, Kartunnen, 1994). These are the often anonymous and unacknowledged actors (Serres, 1993) who have 'made' globalization over the centuries (Holton, 2005). These linguistic mediators have been characterised as the 'anonymous heroes' of cross-cultural communication (de Certeau and Giard, 1983). Their actions were always at least two-fold in nature, combining their primary activities with their translation and interpreting practices, the former necessitating the latter, and the latter making possible the former.

The linguistic elements of translation processes encompass understandings and misunderstandings (Vlasova, 1999), 'dialogue, exchange, [and building] bridges', as well as verbal domination and exclusion (Veit, 2008: 417). Those engaged in translation have been involved variously in the production of mutual intelligibility between groups (and sometimes mutual unintelligibility too), as well as the constructive creation of recognitions of difference by different groups, and the destruction of difference in the favour of more powerful parties (Ribeiro, 2004). In more negative cases, translators of various sorts have helped to construct and corroborate dominant groups' senses of their own superiority, thereby devaluing, ignoring, silencing, and reducing the words and values of the less powerful (Frow, 1995). Language imposed upon a conquered group, forcing them to speak in the language of the conquerors, can involve total or partial cultural assimilation, or even annihilation. Translations may be licensed by authorities, or seek to undermine those authorities (Lefevere, 1990). Representatives of 
conquered, subordinate or marginal groups might adapt, parody or otherwise subvert the linguistic pretensions of the dominant. Translation is usually both multivalent and ambivalent, even in situations where the dominant seem to hold all the advantages (Deleuze and Guattari, 1986).

In more positive cases, which some scholars today might label as historical instances of 'cosmopolitan encounters', each side of a translation process may have begun to see themselves through the eyes of their interlocutors, and then possibly coming to incorporate the linguistic Other partly in their own self-image, perhaps prompting new forms of self-reflection and interrogation of their own identity and culture (Bielsa, 2014). That is why translators have not only been go-betweens, but sometimes also have been get-betweens, challenging cultural assumptions, especially of the dominant groups involved in interchanges, and creating new, more mixed and hybrid words, ideas and worldviews (Ribeiro, 2004). Sometimes translations have operated as transformations, subversions and hijackings of orthodoxies and hegemonic linguistic and cultural dispositions (Koskinen, 2000).

\section{Translation and Places}

In addition to the people who, through translation and interpreting have created globalization processes and made them possible, we should also examine the places where such activities have been undertaken. As Pratt (1991) notes, large cities have throughout history in all parts of the world been crucial 'contact zones' between different cultural and linguistic groups. Metropolises, major harbours, entrepôts and trading centres have acted as cosmopolitan crucibles of translation practices. If it is the case that 'no city is monolingual' (Meylaerts and Gonne, 2014: 133), with linguistic plurality being the general historical norm, then we would expect to find within them the enactment of all manner of relations between languages and language groups. Such relations encompass socio-cultural struggles and shifting, linguisticallymediated power relations on the one side, and mutual influence, interpenetration and instances of trans-community understanding and appreciation on the other.

The former, more negative, sorts of processes have been dramatically illustrated in the cases of long-standing multi-lingual cities like Thessaloniki and Vilnius, which were linguistically purged at specific times in their history by new ruling groups intent on imposing novel monoglot regimes. Such trends have often been motivated by conservative factions in the ruling group regarding the large city as corrupted, both linguistically and otherwise, and as the antithesis of small town and rural heartlands where monolingual purity is apparently a dominant virtue (Cronin and Simon, 2014). We can also note the tendency of tourist industries today either to continue and extend older processes of erasure of the polyglot history of a city, or conversely to highlight and celebrate previous situations of linguistic complexity and heteroglossia in the lived urban fabric of the past (Sywenky, 2014).

The more positive kinds of phenomena alluded to above can be seen in instances of 'in-between' cities like Trieste, where multiple major languages - in this case German and Italian - have both co-existed alongside, and have informed, distinctive local dialectics and patois. In multiple language cities, for example Ottoman Istanbul, the work of translators has often been particularly complex and subtle. There may be indefinite borderlines between source and target languages, with authors often engaging in acts of self-translation, such that it becomes ever more unclear - to both participants at the time, and to later observers - which is the 'native' and which the 'non-native' language, both of a given author and of the city in which they lived (Demirkol-Erturk and Paker, 2014). 
Universities, which are themselves a pre-eminently urban phenomenon, have been institutions where translation practices have very often been concentrated throughout history. Pre-modern universities were often, if not indeed always, trans-national rather than localised in nature and orientation. They have operated in and through the great international languages of their times and places, such as Latin and Arabic. These sorts of languages, which were used and understood across great swathes of the planet, were deployed in the pedagogy and scientific endeavours of the universities, being used as highly convenient and productive lingua franca (Lo Bianco, 2014).

This was as much the case in India as the Arabic and Latin worlds, with universities in the subcontinent in the medieval period attracting people from vast cultural areas, just as their counterparts did in places like Cairo and Paris (Lo Bianco, 2014). These processes point to broader trajectories of Buddhist, Hindu and Islamic cosmopolitanism (Pollock, 2006, Euben, 2008), which of course merit quite as much scholarly attention today as do Christian/European versions of cosmopolitan thought and quotidian practice. Medieval universities across different parts of Eurasia were in some ways quite as 'global' in their functioning as those today. They gathered up scholars from all over the extensive geographical area covered by the language(s) they operated in, as well as those from outside those culture areas, to allow for the comprehensive study of issues that were defined to be of truly 'universal' significance. Such study was often defined as requiring scholarly adeptness in multiple languages, at least those deemed to contain or express significant forms of learning.

At the same time, language was used in more parochial and instrumentalist ways, with teaching being greatly oriented towards languages and knowledges directly useful to a given university's sponsors, such as European students being inculcated with Latin for the purposes of religious and political administration (Bleich, 2008). So, just as in the broader case of cities, so too in the case of universities does the historical record attest to the ongoing and complicated interplay of more monoglot-hegemonic and more polyglot-cosmopolitan dynamics. On the one side, religious and state officials and evangelists have at times sought to suppress the use of specific languages in universities in favour of specific dominant ones. But the opposite situation has also applied too, with the flourishing of cross-cultural communication through translation also being an important element of university life at many points in time (Bleich, 2008).

\section{Globalization/Translation/History: Some Pre-Modern Eurasian Examples}

In this section, we will pursue and illustrate some of the more general points set out above, by considering more particular instances of translation practices, looking at how these have been embedded within, and expressive of, those dynamics of trans-national and cross-group interaction that can be understood under the umbrella term of 'globalization'. This involves renarrating some otherwise famous and familiar cases of translation, especially 'Western' cases, in a new light, emphasizing their complex, hybridized and trans-cultural nature and genesis. We will focus on examples from Eurasia, ranging from ancient times to the $16^{\text {th }}$ century $\mathrm{CE}$, to illustrate some broader points.

As Barnstone (1993) points out, a modern mindset tends to separate supposed original 'authors' from apparently derivative 'translators', according most or all of the literary and aesthetic glory to the author. This point certainly applies in the case of the long-standing and widely held belief that Homer was the first genuine auteur in the so-called 'Western' tradition. But in fact, Homer was an editor, compiler, and re-teller of tales which he gathered from around his cultural world, and which he may have translated from other linguistic sources beyond his native Greek. 
This point raises further issues about how translation processes, now partly or wholly occluded to our view today, were responsible for creating literary works which were subsequently construed as the essential flowering of self-enclosed literary and cultural communities. Given the widespread presence of Greek language in the East, especially through the conquests of Alexander the Great in the $4^{\text {th }}$ century BCE, it may be that at least parts of the Ramayana, the great Sanskrit epic which is one of the great poems of ancient India, may owe some debt to Homer. In a reverse cultural and linguistic flow, this time from East to West, the major work of Roman propaganda, Virgil's Aeneid, which was explicitly modelled on Homer's Odyssey, was partly influenced by the Mahabarata, the other major Sanskrit epic (Frankopan, 2016). These literary works may be regarded as the partial results of the cross-cultural and translinguistic flows promoted by those pan-Eurasian trade networks that some scholars would put under the heading of Eurasian proto-globalization (Pieterse, 2012).

The case of the Aeneid is particularly interesting, as the Romans seem to have been remarkably uninterested in direct and explicit translating from any other language than Greek. There seem to have been almost no translations from Eastern languages (Barnstone, 1993). Even when engaged in Greek translations, Roman literati were notably uninterested in retaining any kind of fidelity to the original, adding in present-day concerns to older texts and often erasing altogether the names of the original authors. Yet at the same time it was Roman culture which eventually passed on to its 'Western' inheritors the major works and ideological concerns of both the Greek and Judaic worlds, with very long-lasting effects not just on Europe but on the whole world (Brague, 2002).

One of the major elements that Rome passed on to later societies was the form of Christianity that first took shape within the eastern part of its empire. Both the Torah and the Koran are still today read in their original languages (Chanda, 2007). The Christian Bible is a very different case, with translations into most of the world's languages today. Here we can discern a fundamental ambiguity in Christianity. On the one hand, there is a two millennia-long set of fears about linguistic entropy, translation of the (variably defined) 'original' being scorned, as it seems to involve loss or perversion of initial perfection, leading in turn to denunciations of translation as heresy and bans on vernacular versions of the holy writings. The Catholic Church banned vernacular translations of the Bible over a remarkably long period, from the $4^{\text {th }}$ to $16^{\text {th }}$ centuries CE, throughout its vast sphere of influence (Moore, 2014). On the other hand, there is a contrary tendency towards the evangelizing need to speak in - and therefore to render the Bible into - the language of potential converts, to be able to win them over to the true path. Monoglot and polyglot tendencies once again are at war with each other. Translation figures as part of both the construction of canonical religious texts, and their transformation and therefore potential destabilization (Barnstone, 1993).

Given this ambiguity, much contemporary scholarship sees the Bible as a radically unstable entity, with both the text itself and the meanings conveyed by it changing according to specific translation practices (Barton, 2019). The contents and sub-titles vary according to the denomination which has commissioned or uses any given translated version. But each faction usually presents its version of the text as pure, definitive and simply the direct expression of the Word of God. Many 'Westernized' versions disguise the Eastern roots of the source texts, which ultimately were originally the linguistic products of Jewish scholars, and in the case of the New Testament, Hellenized ones who operated across Greek and Jewish linguistic and cultural domains. Much of the Old Testament, and most of the New Testament, are in fact disguised translations, and they should not be seen at all as mono-linguistic and mono-cultural products. Translation processes have hidden likenesses and connections between the Judaic 
and other religious traditions, but with traces of these connections left in the texts for expert readers to discern (Barnstone, 1993).

For example, in the Old Testament, the Judaic conception of God derived from the Canaanite deity El, who through complex mediation processes became the Hebrew Elohim. In the Hebrew text, the name retains a sense of ambiguity: is God one or many? Sumerian and Babylonian elements were also suppressed but left hanging obliquely in the Old Testament texts. El's offspring Baal, one of God's other incarnations, eventually became Beelzebub, God's antagonist (Barnstone, 1993). These textual trace bear witness to the fact that in the ancient Near East, individuals and groups moved about incessantly, ideas went with them and became mixed with those of other groups, and new scriptures were as a result created, at the same time as denials were enacted of any cultural and linguistic impurities in the texts. The central and influential Septuagint translation into Greek of Hebrew-Aramaic texts was aimed at Greekspeaking Jews living in the broadly Greek-speaking world of the $3^{\text {rd }}$ and $2^{\text {nd }}$ centuries BCE. It was quoted more in the New Testament scriptures than the Hebrew version as more Jews spoke Greek than Hebrew by that time, reflective of broader cultural and political processes in the region (Moore, 2014).

The New Testament is also a hybrid production. The texts were translated into Greek mostly from lost Aramaic sources, possibly oral as well as textual, which were presented as the original Gospels. Successive translation processes purged Jesus (originally Joshua), his mother (originally Miryam), his family and his disciples of their 'Jewish' characteristics, rendering them mysteriously unaffiliated persons of no specific ethnicity or language. A major ideological shift occurred as a result: Christianity was no longer framed as a dispute within Judaism, but as a rift between two novel groups, 'Christians' and 'Jews', the latter ever more defined as morally lacking or wholly wicked. Translation has again and again over time concealed itself, creating a new and original product, which gives the appearance of literalism and of being the original itself. Successive Greek, Latin, English and German translations - to name only a few major target languages - of Old and New Testaments have been claimed as authoritative by those with vested denominational interests in presenting them so. For example, for 400 years, many English speakers have experienced the King James translation of the Bible as the genuine words of God, speaking to them directly, with any divergences from the sonorous language of the $17^{\text {th }}$ century CE being a matter of often grave dispute (Barnstone, 1993).

Perceptions of textual purity occlude the actual history of inter-textual influences that are themselves expressions of inter-cultural processes. Understanding this involves reconstructing the movements of translators across cultural boundaries and along highways of cultural influence, which in turn were made possible by political, military and trading routes. Thus the $4^{\text {th }}$ century CE evangelist Ulfila worked in both Bulgaria and Constantinople to translate over the course of 40 years the Greek translation of the Christian scriptures into the Gothic language, further spreading Christianity into that cultural world (Santoyo, 2006). In the $5^{\text {th }}$ century CE, Armenian scholars were sent by religious authorities to Constantinople, to gain access to Greek translations of the Bible, so as to improve existing Armenian ones. As Cronin (2003: 26) remarks, repeatedly the 'product of one translation process becomes a tool in the commencement of another'. The more translations there are into more languages, the more potential sources of conflict there may be, as well as greater reach into new regions. Serious disputes over Bible interpretation accompanied the spread of Christianity, as texts moved from Syriac into Greek, and when the Eastern church spread into Arabia and central Asia in the $6^{\text {th }}$ century CE, in turn creating the need for more translation work (Frankopan, 2016). 
Over subsequent centuries, as the Bible was translated into languages like Armenian, Georgian and Coptic, sometimes preserving subsequently lost originals along the way, the translational route was often 'long and devious, from Greek into Syriac or Hebrew, thence into Arabic and thence into Latin, often with Spanish as an intermediary' (Haskins, 1979: 281). Within such processes, both translations and translators travelled, over often long distances. For example, Irish monks re-evangelized major parts of Europe, where Christian belief had fallen into desuetude or had never existed, throughout the $6^{\text {th }}$ to $8^{\text {th }}$ centuries CE. Moving through France, the low countries, Germany, Switzerland and Italy, they promoted education in Latin and produced Latin translations of Greek works (Cronin, 2003).

Interactions between different (but usually empirically overlapping) religious and political civilizational complexes may be understood as forms of early or proto-globalization (Inglis, 2010). Relations between the various Christian churches and the newly ascendant religious and political power of Islam involved multiple and complicated translation practices. As far as we know, between the $7^{\text {th }}$ and $10^{\text {th }}$ centuries CE, only one Western book was translated into Arabic, but large numbers of other, more prosaic kinds of documents flowed both ways at this time (Santoyo, 2006). Translation was an important practice in the various Islamic centres of learning, involving various sorts of inter-cultural influence. In late $8^{\text {th }}$ century CE Baghdad, the dynamic nature of translation processes can be seen in the fact that knowledge of algebra, a new discovery, inflected the translations made of earlier, pre-algebraic Greek mathematicians (Cronin, 2003). In the same city in the $9^{\text {th }}$ century, important translators like Abû Utmân alJâhiz and the Arab Nestorian Christian Hunayn ibn Ishaq were at work; the latter translated key texts from Greek into Syriac and Arabic. The Baghdad-based Persian mathematician AlKhwarizmi introduced Hindu numerals and the concept of zero to Arab mathematics, which were then subsequently introduced by Latin translators to Europe in the $12^{\text {th }}$ century (Chanda, 2007). Al-Hasan ibn Suwâr al-Hammar translated Aristotle into Arabic around $1000 \mathrm{CE}$ (Santoyo, 2006).

In the $10^{\text {th }}$ century $\mathrm{CE}$, within the Abbasid and Mughal empires, translations of texts that were meant to facilitate better societal administration, were very expressive of linguistic and cultural heterogeneity. In Abbasid Baghdad translations aimed at reviving and reworking ancient Arabic, Sanskrit, Persian and Greek knowledges, with the resulting translations building a common way of communicating in a strongly multi-lingual context (Selim, 2009). Scholars from these linguistic groups and others were invited to participate in the translating process. Often the translations made at this time are the only ones left to us today, the originals (or in some cases, earlier translations) having been lost. The Umayyad rulers of Spain sent agents across the Islamic sphere of influence, to Baghdad, Cairo, Damascus and other locations, to buy books in multiple languages and to attract scholars and translators. Eventually the rich libraries of Islamic Spain would be crucial resources for the scholars and translators of the socalled 'European' Renaissance of the $15^{\text {th }}$ and $16^{\text {th }}$ centuries. Muslim translators were also linchpins connecting their world to other civilizational complexes, notably India. Located in the relatively peripheral location of Afghanistan, in the early $11^{\text {th }}$ century CE the polymath AlBiruni learnt Sanskrit, wrote an influential account of the subcontinent, and translated and transmitted works of classical Indian literature to the Muslim world (Chanda, 2007).

It has been tempting for modern scholars to present times and places of intense translation activity as involving formal, institutionalised 'schools' of translators. But just as there was no formalised 'Baghdad School' of translators turning Greek texts into Arabic, so too, despite subsequent myth-making, was there no such School in $12^{\text {th }}$ century CE Christian Toledo, that supposedly brought translators from across Spain, Italy, England, the low countries and further afield to translate Arabic and Greek texts (Santoyo, 2006). Nonetheless, the so-called 
Renaissance of the $12^{\text {th }}$ century involved intensive translation activities, dispersed across key centres in Western Christendom, such as the earliest European universities like Salerno and Bologna. At the same period, the Norman rulers of Sicily developed the island as an intellectual entrepôt, commissioning original scientific works in Arabic, as well as translations of Arabic science into Latin (Takayama, 2003).

The 'discovery of Greek and Arabic texts provided a qualitative change in Europe's intellectual atmosphere that motivated students to look into how these texts might affect canon law, civil law, and religious practices' (Bleich, 2008: 501). Students from all over Europe subsequently came to such places of learning to learn about the new knowledges created from old translated texts. It was often Jewish translators, placed between different cultural worlds and living in places where different groups and languages met, who provided the translations (Haskins, 1979). Translations from Arabic coming out of Spain yielded the west European (re)discovery of Aristotle, some of whose works became available about $1200 \mathrm{CE}$, along with Galen and Hippocrates. It was often accidental whether the version of a text that came into wider circulation was taken from either a Greek or Arabic version of it. But the glosses provided by Arabic scholars on the Greek originals often had a major impact on how Western scholars took up and made sense of those originals (Bleich, 2008).

The historian Janet Abu-Lughod (1989) has argued that in the $13^{\text {th }}$ century CE, the Middle East, the Indian Ocean area, China and Europe were becoming ever more integrated by the connection of major trading hubs linked by sea and land trade routes. This was in large part made possible by the vast expansion of the Mongol empire across much of Eurasia. Santoyo (2006: 16) makes the point that at that time 'not a single book seems to have been translated between Mongolian and any European language, Latin included'. Nonetheless, 'the chronicles of the mutual relations' between Westerners and Mongols abound with 'messages, letters and documents which went to and fro in the hands of successive emissaries (William of Rubruc, friar Giovanni di Pian del Carpine, and friar Ascelino of Cremona among them), translated from Mongolian into Latin, from Latin into Russian, Persian, or Mongolian, from Greek into Mongolian, from Latin into Arabic or Syriac, and so forth'. The constant movement of translators and translations, usually done on-the-hoof while multiple sorts of people moved along the trade routes, is a key feature of pre-modern Eurasian globalization.

Contemporary scholarship often re-narrates phenomena that have for a long time been understood to be products of self-enclosed cultures, especially so-called 'European' ones, in light of broader, trans-regional processes, including pan-Eurasian dynamics. For example, the so-called 'European' Renaissance of the $15^{\text {th }}$ and $16^{\text {th }}$ centuries CE is better described as a transnational cultural movement. This is partly because it involved Ottoman Turkey as much as it did places we conventionally associate it with, such as Italy (Inglis and Robertson, 2005). It is also partly because it involved the discovery and putting to use of translated texts preserved by Arab scholars, many of which were the only surviving copies of the original works of Greek authors. But such translations from Arabic into the various early modern European languages were presented in ways that created spurious direct relations between the Greek texts and the target languages, cutting Arabic out of the transmission story, and therefore out of the history of the Renaissance itself (Cronin, 2003: 39).

\section{Conclusion}

This chapter has laid out some of the main contours of the relations between historical globalization and translation. It has done so at two levels, considering both general types of those relations, and specific, real-world instances of them. It has been seen that multiple types 
of actors - professional translators, non-professionals who were engaged in translation activities, interpreters, and so on - have all contributed to the making and running of globalization processes. There is no current scholarly agreement as to how to define the latter, or to say how long they have existed. Nonetheless it is clear that, however globalization in history is understood, translation and interpreting practices have been crucial in forging connections of multiple types between different human groups and the places where they have dwelled. It remains the case that translation studies and the historiography of translation still need to integrate more fully models of historical globalization into their intellectual skill-set, just as students of long-term globalization must place translators and translation much more at the forefront of their analytic purview. This chapter has sought to contribute a grounding for future constructive rapprochements in that direction.

\section{Further Reading}

Bastin, G. and Bandia, P. (eds.) (2006) Charting the Future of Translation History, Ottawa: Ottawa UP

An intriguing collection of essays which touch upon multiple globalization/translation issues.

Cronin, M. (2003) Translation and Globalization, London: Routledge

A wide-ranging analysis of "modern" globalization processes on translation practices

Gills, B. and Thompson, W. (eds.) (2006) Globalization and Global History, London: Routledge

Offers comprehensive overviews of the problems involved in examining historical globalization.

\section{References}

Abu-Lughod, J. (1989) Before European Hegemony, New York: Oxford University Press

Appiah, A. (1995) 'Geist Stories', in Bernheimer, C. (ed.) Comparative Literature in the Age of Multiculturalism, Baltimore: Johns Hopkins UP

Bandia, P. (2006) 'The Impact of Postmodern Discourse on the History of Translation', in Bastin, G. and Bandia, P. (eds.) Charting the Future of Translation History, Ottawa: Ottawa UP, pp. $45-58$

Barnstone, W. (1993) The Poetics of Translation, Yale: Yale UP

Barton, J. (2019) A History of the Bible: The Book and Its Faiths, London: Allen Lane

Bayly, C. A. (2002) "Archaic" and "Modern" Globalization in the Eurasian and African

Arena', in Hopkins, A. G. (ed.), Globalization in World History, London: Pimlico, pp. 47-73

Bentley, J. (1999) 'Cross-Cultural Interaction and Periodization in World History', American Historical Review, 101(3): 749-770

-(2006) 'Globalizing History and Historicizing Globalization' in Gills, B. and Thompson, W. (eds.) Globalization and Global History, London: Routledge, pp. 16-29

Bielsa, E. (2014) 'Cosmopolitanism as Translation', Cultural Sociology, 8(4): 392-406 
-(2016) 'News Translation: Global or Cosmopolitan Connections?', Media, Culture and Society, 38(2): 196-211

Bleich, D. (2008) 'Globalization, Translation and the University Tradition', New Literary History, 39(3): 497-517

Brague, R. (2002) Eccentric Culture, South Bend: St. Augustine's Press

Chanda, N. (2007) Bound Together: How Traders, Preachers, Adventurers, and Warriors Shaped Globalization, Yale: Yale UP

Cronin, M. (2000) 'History, Translation, Postcolonialism' in Simon, S and St.-Pierre, P. (eds.) Changing the Terms: Translating in the Postcolonial Era, Ottawa: Ottawa UP, pp. 33-52

Cronin, M. (2003) Translation and Globalization, London: Routledge

Cronin, M. and Simon, S. (2014) 'The City as Translation Zone', Translation Studies, 7(2): $119-132$

de Certeau, M. and Giard, L. (1983) 'L'Ordinaire de la Communication', Réseaux, 1(3): 3-26

Deleuze, G. and Guattari, F. (1986) Kafka: Toward a Minor Literature, Minneapolis:

Minnesota UP

Demirkol-Erturk, S. and Paker, S. (2014) 'Beyoglu/Pera as a Translating Site in Istanbul', Translation Studies, 7(2): 170-185

D’hulst, L. (2012) '(Re)Locating Translation History', Translation Studies, 5(2): 139-155

Euben, R. (2008) Journeys to the Other Shore, Princeton: Princeton UP

Frank, A. G. and Gills, B. (1993) The World-System: Five Hundred Years or Five

Thousand?, London: Psychology Press

Frankopan, P. (2016) The Silk Roads, London: Vintage

Frow, J. (1995) Cultural Studies and Cultural Value, Oxford: Oxford UP

Gills, B. and Thompson, W. (eds.) (2006) Globalization and Global History, London:

Routledge

Haskins, C. H. (1979) The Renaissance of the 12h Century, Harvard: Harvard UP

Holton, R. (2005) Making Globalization, London: Palgrave

Hopkins, A. G. (ed.) (2002) Globalization in World History, London: Pimlico

Inglis, D. (2005) Culture and Everyday Life, London: Routledge

Inglis, D. (2010) 'Civilizations or Globalization(s)? Intellectual Rapprochements and Historical World-Visions', European Journal of Social Theory, 13(1): 135-152

Inglis, D. and Robertson, R. (2005) 'The Ecumenical Analytic: 'Globalization', Reflexivity and the Revolution in Greek Historiography', European Journal of Social Theory, 8(2): 99122.

Inglis, D. with Thorpe, C. (2019) An Invitation to Social Theory, Cambridge: Polity.

Kartunnen, F. (1994) Between Worlds: Interpreters, Guides and Survivors, New Brunswick:

Rutgers UP 
Koskinen, K. (2000) Beyond Ambivalence, Tampere: Acta Universtiatis Tamperensis, 774 -(2014) 'Tampere as a Translation Space', Translation Studies, 7(2): 186-202

Lefevere, A. (1990) 'Translation: Its Genealogy in the West', in Bassnett, S. and Lefevere, A. (eds.) Translation, History and Culture, London: Pinter, pp. 14-28

Lo Bianco, J. (2014) 'Domesticating the Foreign: Globalization's Effects on the Place/s of Languages', Modern Language Journal, 98(1): 312-325

McKeown, A. (2007) 'Periodizing Globalization', History Workshop Journal, 63: 218-230

Meylaerts, R. and Gonne, M. (2014) 'Transferring the City - Transgressing Borders',

Translation Studies, 7(2): 133-151

Moore, R. (2014) 'The Case for Bible Translation, Viewed in Historical Perspective', The Bible Translator, 65(1): 77-87

Olohan, M. (2014) 'History of Science and History of Translation', The Translator, 20(1): 925

Pieterse, J. N. (2012) 'Periodizing Globalization: Histories of Globalization', New Global Studies, 6(2): Article 1

Pollock, S. (2006) The Language of the Gods in the World of Men, Berkeley: University of California Press

Pratt, M. L. (1991) 'Arts of the Contact Zone', Profession, 33-40

Ribeiro, A. (2004) 'Translation as a Metaphor for Our Times', Portuguese Studies, 20: 186194

Roland, R. (1999) Interpreters as Diplomats: A Diplomatic History of the Role of Interpreters in World Politics, Ottawa: Ottawa UP

Santoyo, J.-C. (2006) 'Blank Spaces in the History of Translation', in Bastin, G. and Bandia, P. (eds.) Charting the Future of Translation History, Ottawa: Ottawa UP

Serres, M. (1993) Hermes: Literature, Science, Philosophy, Baltimore: Johns Hopkins UP

Selim, S. (2009) 'Nation and Translation in the Middle East', The Translator, 15(1): 1-13

Steiner, G. (1996) No Passion Spent: Essays, Yale: Yale University Press

Sywenky, (2014) '(Re)Constructing the Urban Palimpsest of Lemberg/Lwow/Lviv', Translation Studies, 7(2): 152-169

Takayama, H. (2003) 'Central Power and Multi-Cultural Elements at the Norman Court of Sicily', Mediterranean Studies, 12: 1-15

Veit, W. (2008) 'Globalization and Literary History', New Literary History, 39(3): 415-435

Venuti, L. (1995) The Translator's Invisibility: A History of Translation, London: Routledge

Vlasova, M. (1999) 'The American Declaration of Independence in Russian', Journal of American History, 85(4): 1399-1408 
